УДК 61:377.4

\title{
ПЕРВИННА СПЕЦАЛЛЗАЦІЯ (ІНТЕРНАТУРА ) “ЗАГАЛЬНА ПРАКТИКА - СІМЕЙНА МЕДИЦИНА”: РЕАЛІЇ СЬОГОДЕННЯ І ПЕРСПЕКТИВИ РОЗВИТКУ
}

\author{
М. В. Гребеник, О. І. Криськів, С. С. Шостак, О. М. Масик \\ ДВНЗ “Тернопільський держсавний медичний університет імені І. Я. Горбачевського МОЗ Украйни”
}

\section{PRIMARY SPECIALIZATION (INTERNSHIP) "GENERAL PRACTICE - FAMILY MEDICINE": PRESENT REALITIES AND PROSPECTS OF DEVELOPMENT}

\author{
M. V. Hrebenyk, O. I. Kryskiv, S. Ye. Shostak, O. M. Masyk \\ SHEI "Ternopil State Medical University by I. Ya. Horbachevsky of MPH of Ukraine”
}

\begin{abstract}
У статті висвітлено деякі аспекти викладання терапії в інтернатурі зі спеціальності “Загальна практика - сімейна медицина" та можливі перспективи їі удосконалення.
\end{abstract}

The article adduces some aspects of teaching therapy in internship on the specialization "General Practice - Family Medicine" and possible prospects of its improvement.

Вступ. Інтернатура - найвищий щабель медичної освіти на завершальному етапі отримання сертифіката спеціаліста. Разом з тим, це - обов'язкова форма післядипломної освіти випускників вищих медичних навчальних закладів, основним завданням якої $€$ поглиблення теоретичної та практичної підготовки лікарів-інтернів; виховання професійної готовності до самостійної роботи; формування сімейного лікаря, як організатора та координатора лікувально-діагностичних та профілактичних заходів тощо [1].

3 огляду на вищевказане, вирішальним підсумком інтернатури має стати виховання покоління фахівців, які будуть ефективно працювати, відчуваючи нагальну потребу навчатись упродовж життя. Таким чином буде забезпечено безперервність післядипломної освіти.

Основна частина. Навчальний план та уніфікована програма для лікарів-інтернів фаху “Загальна практика - сімейна медицина" розрахована на 2 роки: 6 місяців (936 годин) протягом першого року - очна частина навчання (на відповідних кафедрах медичних вищих навчальних закладів); 5 місяців (780 годин) - робота в амбулаторіях (відділеннях) сімейної медицини. Протягом другого року: 4 місяці (624 години) - навчання на очному циклі; 7 місяців (1092 години) - робота в амбулаторіях [1].

Навчання в інтернатурі, перш за все, повинно сприяти засвоєнню професійних навичок і вмінь. На нашу

() М. В. Гребеник, О. І. Криськів, С. Є. Шостак, О. М. Масик думку, як можливу перспективну модель, варто розглянути наступну: один місяць - ознайомлення із заочною базою, іiі можливостями та складання індивідуального плану навчання; далі - чотири місяці очний цикл; шість місяців - знову стажування на заочній базі.

Під час очного циклу першого року навчання (вересень - грудень) повинні бути вирішені такі важливі питання: 1) відпрацювання алгоритмів діагностики і лікарської тактики при найпоширеніших клінічних синдромах завдяки лекційній підготовці, семінарським і практичним заняттям; 2) уточнення плану роботи на заочній базі; 3 ) налагодження системи зв' язку і контролю навчання за дистанційним принципом. Заочний цикл на першому році навчання повинен бути тривалішим, ніж діючий на даний час (7 місяців, або 1092 години проти 5 місяців, або 780 годин). Таким чином, акцент у підготовці молодих лікарів буде перенесено на практичну роботу. В цьому випадку молодий спеціаліст буде самостійно проводити всі етапи діагностики, лікування і профілактики захворювань. Якщо врахувати, що за день роботи в амбулаторії (відділенні) сімейної медицини лікар повинен оглядати не менше 15 хворих, то за перший рік стажування на заочній базі він огляне достатньо велику кількість пацієнтів, що принесе йому ряд позитивів: 1) вміння швидко діагностувати різноманітну патологію і приймати правильне рішення; 2) направ- 
ляти пацієнта лише на необхідне додаткове обстеження; 3) призначати адекватне лікування; 4) відслідковувати віддалені його результати. Перші помилки, або неможливість зорієнтуватись у діагнозі, будуть стимулювати інтернів до поглибленого вивчення проблемних питань, а також до співпраці з досвідченими лікарями. Додатковим позитивним моментом $є$ те, що на заочній базі стажування навчальний процес контролюють начмеди і завідувачі відділень, які досконало знають різні аспекти практичної діяльності сімейного лікаря. Контроль за підготовкою інтернів на заочній базі можна було б здійснювати дистанційно, а саме у вигляді: 1) індивідуальних консультацій із викладачем-куратором в режимі on - line - у фіксований час; 2) “інтернет-конференцій” - 1 раз на тиждень із розбором конкретного клінічного випадку; 3) електронного звіту про виконану роботу за місяць (за розробленою стандартною формою). Крім того, на другому році навчання більше уваги слід було б приділяти цілеспрямованій теоретичній підготовці за запитами інтернів та результатами їх самостійної практичної роботи. Саме тоді, коли інтерни набудуть мінімального досвіду практичної роботи і зіткнуться iз першими труднощами, викладачі кафедр університету зможуть допомагати отримувати знання чи удосконалювати (або й набувати) необхідні практичні навички. Тоді можна було би у групі предметно обговорювати реальні клінічні випадки 3 практики інтернів, відстежувати діагностичний пошук чи лікування, призначене молодим лікарем, аналізувати помилки і виправляти їх. Це свого роду рольові ігри, що базуються на реальних подіях. При такій моделі навчання розподіл годин на другому році навчання виглядав би таким чином: серпень - грудень - продовження стажування на заочній базі (5 місяців - 780 годин); січень - червень - навчання на відповідних кафедрах університету (6 місяців - 936 годин).

Крім того, на нашу думку, на другому році навчання варто було б також розглянути можливість додаткового вивчення і освоєння проведення різних методів функціональної діагностики, наприклад, ультразвукової діагностики (УЗД), езофагогастродуоденоскопії (ЕГДС), елементарних лабораторних досліджень із використанням тест-систем. Вказана необхідність зумовлена тими вимогами, які у всьому світі ставлять до сімейних лікарів: самостійно обстежувати пацієнтів. Отже, в майбутньому і наші українські лікарі загальної практики-сімейної медицини повинні вміти обстежувати пацієнта відповідно до патології, провівши електрокардіограму, УЗД, ЕГДС, спірометрію, акушерське чи інше обстеження. Таким чином, відпо- відно до нашої пропозиції, практичні навички сімейного лікаря із рубрики “клінічна інтерпретація результатів дослідження" типової програми навчання в інтернатурі перейдуть в рубрику “спеціальні навики”, що буде відповідати світовим стандартам діагностики і лікування захворювань.

Окремим пунктом хочемо виділити надзвичайно перспективний напрямок практичної підготовки лікарів-інтернів у навчально-практичних центрах первинної медико-санітарної допомоги, що розміщені в селах Тернопільської області. Для майбутніх лікарів - це чудова можливість випробувати свої сили, розібратись в тому, що добре засвоїли, а над чим слід ще попрацювати під час навчання на кафедрах університету [2]. Молоді лікарі під керівництвом викладачів мають можливість проводити профілактичні огляди сільського населення, самостійно записувати ЕКГ, реально вирішувати питання первинної і вторинної профілактики, при потребі - надавати невідкладну допомогу [3]. Інтерни, в день здачі зміни, мають можливість вчитись на справжніх "майстер-класах" викладачів, висококваліфікованих спеціалістів, які проводять прийоми заздалегідь підібраних тематичних хворих. За час навчання в інтернатурі кожен молодий лікар декілька разів працює в такому навчально-практичному центрі, де умови роботи і навчання максимально наближені одна до одної.

Формуванню професійної готовності до самостійної практичної роботи сприяють також виступи інтернів на лікарських і наукових конференціях, терапевтичних товариствах. У більшості випадків, через недостатній практичний і ораторський досвід, молодим лікарям робити це досить складно. Тому на кафедрі терапії і сімейної медицини факультету післядипломної освіти запроваджено щоденні ранкові конференції, під час яких лікарі-інтерни вчаться доповідати про стан пацієнтів, оглянутих ними напередодні; правильно формулювати діагнози; аналізувати динаміку стану тяжко хворих. Виступ на конференції включає також клінічний розбір хворого, вибраного інтерном на курацію. Інтерни підходять до цього творчо: кожен готує мультимедійну презентацію з обов' язковим посиланням на протоколи діагностики і лікування, регламентовані MO3 України, а інколи - ще й невеликі виступи по вибраній нозології (особливо рідкісній). Це полегшує сприйняття інформації аудиторією і підвищує рейтинг доповідача. Спілкуючись з інтернами, ми 3'ясували, що чим частіше вони виступають, тим швидше готуються на наступний раз, менше хвилюються і краще відповідають на запитання, яких завжди достатньо. Таким чином, на таких конференці- 
ях реалізовуються два аспекти: навчальний та прикладний (або поєднання теорії і практики).

Підсумовуючи вищевказане, хочеться зазначити, що на етапі реформування медичної галузі суттєво зростають вимоги до організації і удосконалення післядипломної освіти. На цьому шляху є багато “вузьких місць” і законодавчої неузгодженості. Проте спільними зусиллями працівників вищої школи, закладів практичної охорони здоров' я та за підтримки MO3 України завжди можна знайти вихід із ситуації, що склалася, якщо творчо підходити до вирішення проблем, які виникають в процесі роботи, покращити систему підготовки лікарів і, таким чином, реально забезпечити інтеграцію наших лікарів у світову медицину.

Висновки: 1. Сучасний навчальний план підготовки лікарів-інтернів фаху "Загальна практика сімейна медицина" має ряд недоліків і потребує ко-

\section{Література}

1 Типовий навчальний план і програма спеціалізації (інтернатури) випускників вищих медичних закладів освіти III-IV рівнів акредитації зі спеціальності “'Загальна практика-сімейна медицина" / МОЗ України.-К., 2002.-74 с.

2. Ковальчук Л. Без університетських лікарень неможли- рекції. Необхідно збільшити кількість годин навчання на заочних базах стажування на першому році навчання в інтернатурі, включити в програму обов'язкові чергування у навчально-практичних центрах первинної медико-санітарної допомоги та володіння функціональними методами діагностики, тощо. Це підвищить зацікавленість майбутніх спеціалістів у поглибленому оволодінні професійними знаннями.

2. Нові комп'ютерні технології (дистанційні форми навчання, використання мультимедійної техніки) дозволяють суттєво покращити якість засвоєння програмного матеріалу: отримати кваліфіковані консультації спеціалістів різних профілів без відриву від основного місця стажування, прослухати нові лекції, обговорити складні випадки з практики за допомогою on-line конференцій. Таким чином, вищевказане піднімає на якісно вищий рівень отримання знань $\mathrm{i}$ практичних навичок в інтернатурі.

во реформувати медицину / Л. Ковальчук // Газета “Дзеркало тижня”, - 2012. - № 4 (52). - 4 лютого.

3. Досвід навчання лікарів-інтернів на базі навчально-практичних центрів ПМСД / М. В. Гребеник, С. С. Шостак, Н. I. Ярема [та ін.]// Сімейна медицина. -2011.-№3.-С. 54. 